\title{
THE NEUROHISTOLOGICAL BASIS FOR THE SENSA- TION OF PAIN PROVOKED FROM DEEP FASCIA, TENDON, AND PERIOSTEUM
}

\author{
BY \\ GRAHAM WEDDELL and J. A. HARPMAN \\ From the Institute of Anatomy, University College, London \\ (Received 7Th August, 1940)
}

THE work of Waterston (1933a, b), Lewis (1938), Kellgren (1938), and others, as well as clinical experience, has established that pain can be aroused from deep fascia, tendon, and periosteum. The present paper deals with the neurohistological basis for the sensation of pain which can be aroused from these tissues.

\section{Physiological Observations}

Experiments were carried out on two human subjects. Sensations were aroused by means of fine, sharp needles.

\section{Experiments on Deep Fascia and Tendon}

Series 1.-Areas of skin and superficial fascia covering the junctions of the biceps brachii muscle with its tendon of insertion, and of the gastrocnemius and soleus muscles with the tendo Achillis, were anæsthetized by infiltration with 4 per cent. novocain solution containing 1 part in 20,000 adrenalin hydrochloride. Fine, sharp needles were inserted through the anæsthetized skin and superficial fascia. No sensations were recorded until the point of the needle reached the deep fascia or peritendinous connective tissue. At this level, either no sensation whatever or sensations of pressure or pain were recorded. Several varieties of pain were distinguished, all apparently commenced as soon as the stimulus was applied. Two main varieties were recorded. One was mild, gave the impression of being sharply "localized," disappeared as soon as the stimulus was removed, and was described as a prick. The other was more severe and diffuse in character, rose gradually in intensity to a maximum, then slowly receded and persisted for a short time after removal of the stimulus. It was described as an ache of peculiarly unpleasant quality. All varieties of pain were spatially independent, the second main variety being experienced more commonly when thicker needles were used.

Series 2.-The skin and superficial fascia over the same musculo-tendinous junctions were anæsthetized as before, and, in addition, the novocain and adrenalin solution was injected into the deep fascia and over the surface of the connective tissue investment of the tendon. Experiments were carried out 
fifteen to twenty-five minutes later. No sensations were aroused until the needle was introduced into the substance of the tendon, when pain was provoked but rarely, and was constantly of the first variety described. Pain of the second variety could not be aroused even when a relatively thick needle, such as a No. 17 hypodermic, was used. On one occasion a single contraction of an isolated group of fibres of the gastrocnemius muscle was observed on insertion of the needle into the tendon substance; this was unaccompanied by any sensation whatever. Pain was aroused when the needle was reinserted into approximately the same site, but no further muscular contraction was observed.

Series 3.-Areas of skin and superficial fascia over the tendo Achillis at a distance of about $7 \mathrm{~cm}$. from the musculo-tendinous junction were anæsthetized. From the deep fascia and peritendinous connective tissue pressure and pain were aroused, as in the first series of experiments. No pain could be aroused from the substance of the tendon in this position before or after anæsthetization of its connective tissue sheath and the overlying deep fascia. A feeling of tension could only be provoked when the tendon was moved as a whole for distances of at least $\frac{1}{4} \mathrm{~cm}$. This sensation was not "localized," but gave the impression of a mass movement of the whole tendon.

\section{Experiments on Periosteum}

Areas of skin and superficial fascia over the subcutaneous surface of the tibia were anæsthetized. Fine, sharp needles were inserted through the anæsthetized areas as far as the bone. Several varieties of pain were aroused from periosteum; they were similar to those provoked from deep fascia and tendon connective tissue sheath, except that the first main type of pain described was frequently referred to a point 2 or $3 \mathrm{~cm}$. distal to the site of application of the stimulus. No other sensations were provoked from the subcutaneous surface of the tibia.

The number of spots from which pain could be aroused in periosteum, deep fascia, and peritendinous connective tissue was less than in the skin of the same subjects (Woollard, Weddell, and Harpman, 1940).

\section{Histological Observations}

Deep Fascia.-In methylene blue preparations of deep fascia from the human leg, three types of nerve ending were found. Finer medullated and nonmedullated nerve fibres form a loose-meshed plexus and give rise to free nerve terminals (Fig. 1). Vater-Pacini and Golgi-Mazzoni corpuscles also occur (Figs. 2 and 3). Many of the Vater-Pacini corpuscles receive, in addition to the principal thick medullated fibre, a fine non-medullated " accessory" nerve fibre which terminates by forming a coil with and around the principal nervous component of the ending (Fig. 2).

Tendon.-In methylene blue preparations of tendons from the extensor muscles of the leg of the rabbit, neuro-tendinous endings of Golgi were found in the vicinity of the musculo-tendinous junction (Figs. 4 and 5). These endings may be disposed in groups (Fig. 4) or as units (Fig. 5). In every instance the specialized ending is borne by a single, thick nerve fibre which is usually 


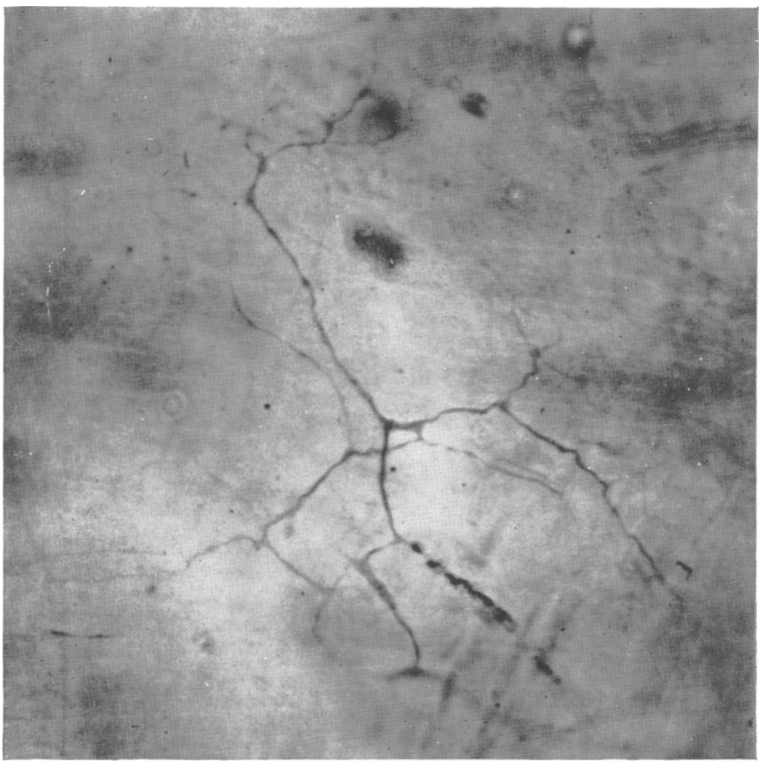

Fig. 1.-Photomicrograph showing a plexus of finer medullated and non-medullated nerve fibres giving rise to free nerve endings; deep fascia of the human leg. Methylene blue preparation. $\times 520$.

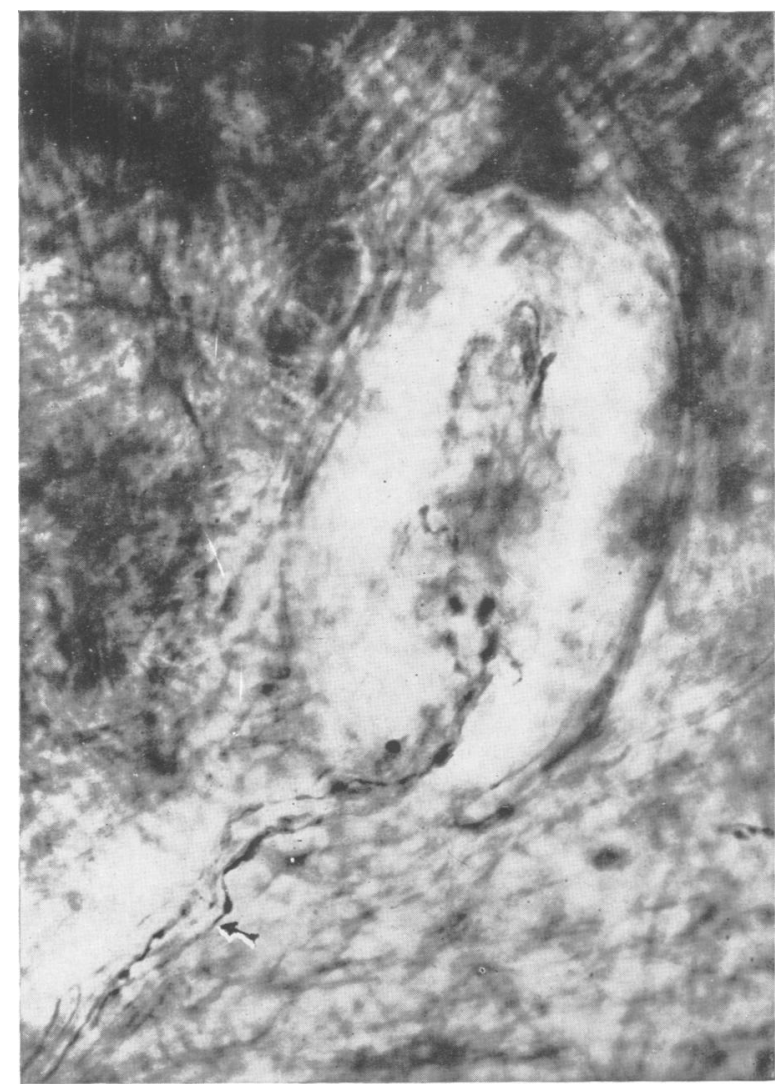

Fig. 2. - Photomicrograph showing a Vater-Pacini corpuscle in the deep fascia of the human leg. The arrow points to the "accessory" fibre. Methylene blue preparation. $\times 475$. 


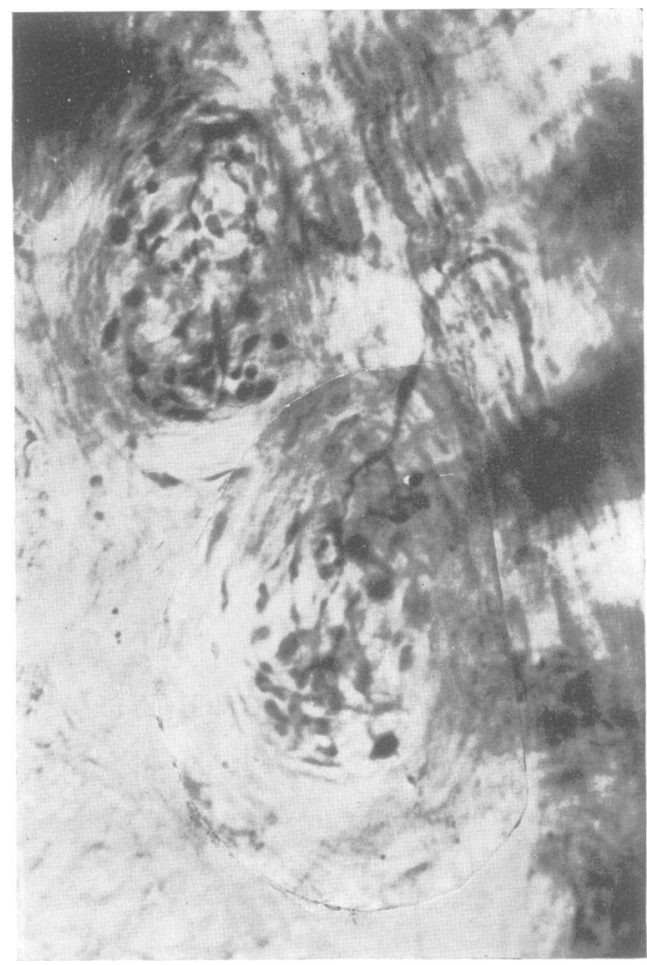

Fig. 3.-Photomicrograph showing Golgi-Mazzoni corpuscles in the deep fascia of the human leg. Methylene blue preparation. $\times 600$.

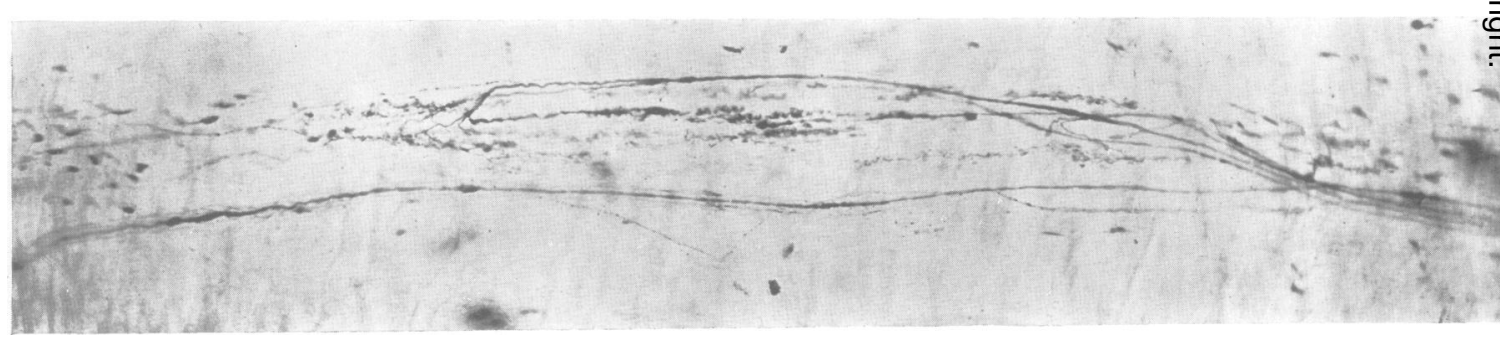

Fig. 4.-Photomicrograph showing a group of neuro-tendinous endings of Golgi and free nerve endings derived from " accessory" fibres in the vicinity of the musculo-tendinous junction of the extensor digitorum longus muscle of the rabbit. Methylene blue preparation. $\times 220$.

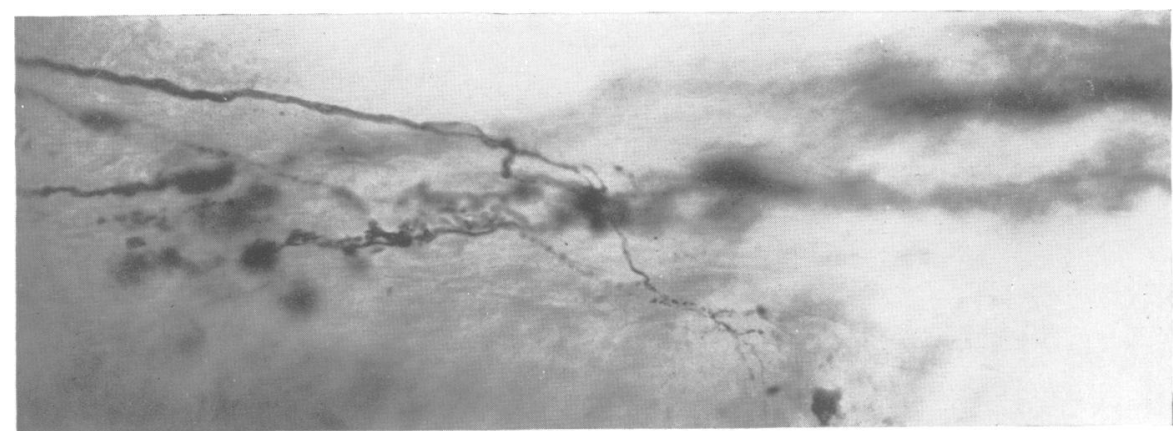

Fig. 6.-Photomicrograph showing free nerve endings derived from an " accessory" fibre accompanying the principal nerve fibre of a Golgi neuro-tendinous ending; the latter is seen in the background. Tendon of the tibialis anticus muscle. Methylene blue preparation. $\times 440$. 


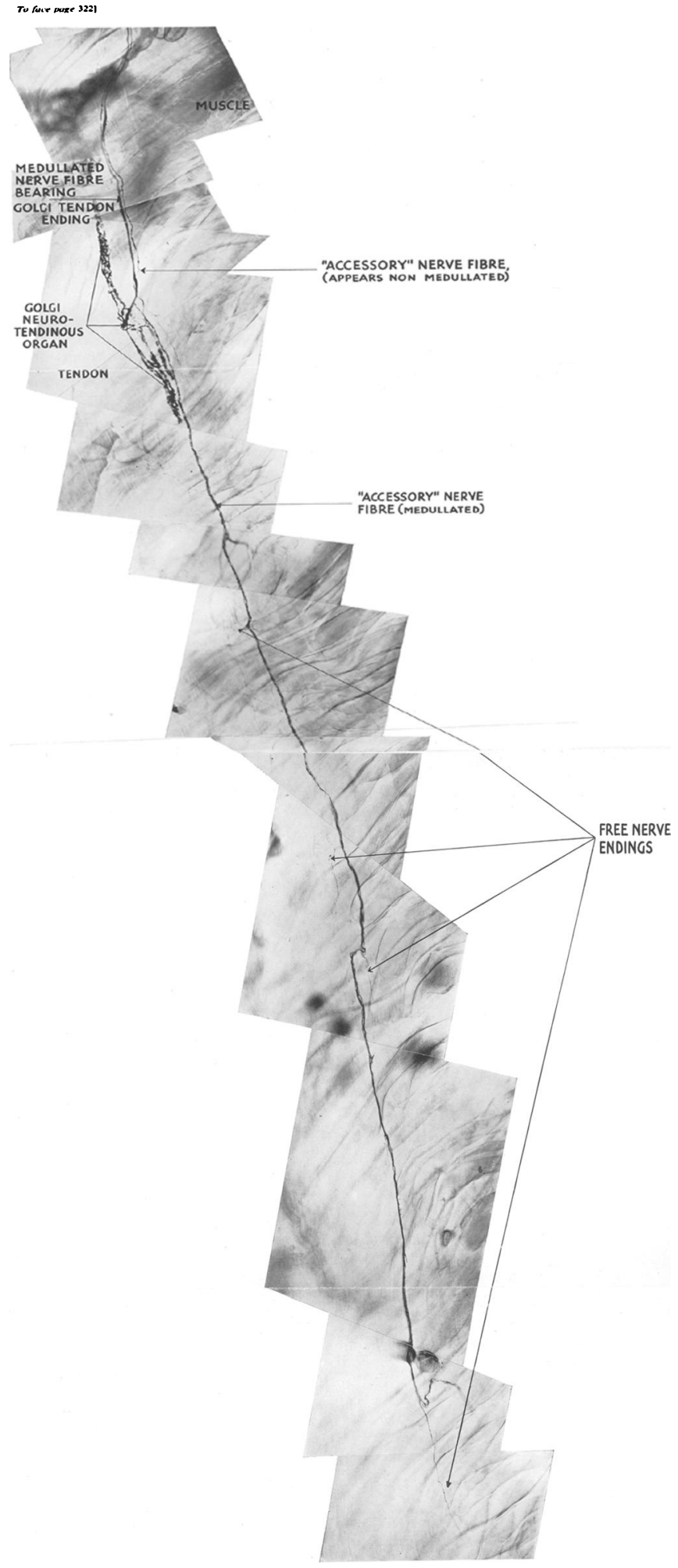

MEDULLATED

BEARING

ENDON

"ACCESSORY" NERVE

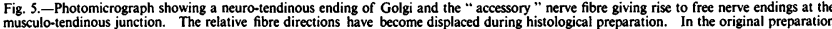
musculo-tendinous junction. The relative fibre directions have become displaced during histological preparation. In the original preparation
the medullated and non-medullated portions of the accessory nerve fibre were clearly seen to be in continuity. This is not obvious in the
photomicrograph owing to the varying focal planes occupied by the nerre fibre. Methylene blue preparation, Rabbit $\times 300$. 
medullated. This fibre is constantly accompanied by an "accessory" nerve fibre which, proximal to the ending, is thin and non-medullated. In the neighbourhood of the neuro-tendinous ending the "accessory" fibre gives rise to fine, varicose, free nerve terminals (Figs. 4, 5, and 6). The " accessory" fibre extends distal to the Golgi ending, becomes thicker in diameter, may become medullated (Fig. 5), and at intervals gives rise to further free nerve endings. The "accessory" fibre in question is similar to "accessory" nerve

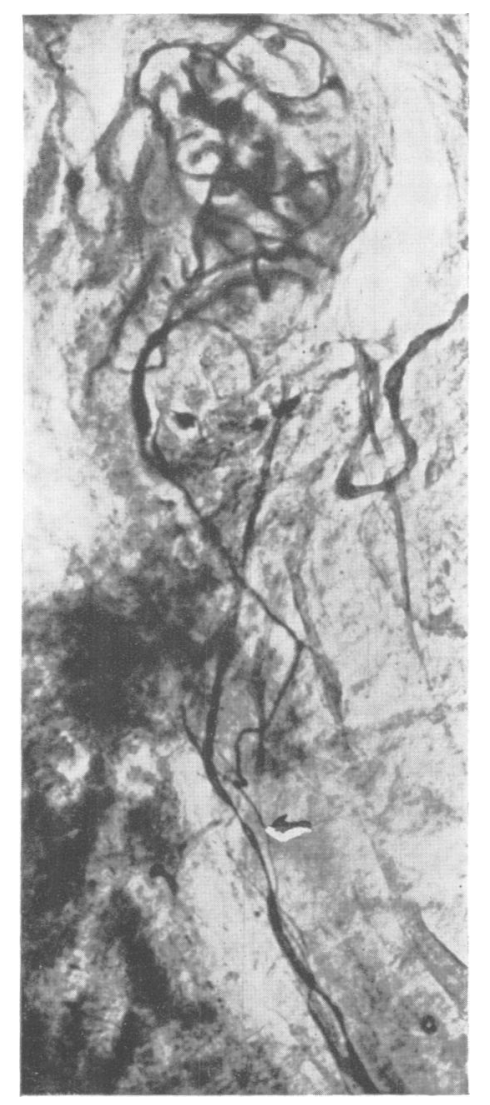

Fig. 7.-Photomicrograph showing a Meissner corpuscle in the human thumb; the arrow indicates the "accessory" nerve fibre, which expands as it approaches the corpuscle and gives rise to free nerve endings. Reduced silver preparation. $\times 570$.

fibres ending in close relation to encapsulated receptors elsewhere (Figs. 2 and 7).

Periosteum.--In methylene blue preparations of periosteum from the mandible of the rat there occur finer medullated and non-medullated nerve fibres giving rise to free nerve endings (Fig. 8). These fibres are arranged in a simple plexiform manner. Endings of tension recording type occurring in periosteum at the origin of the genioglossus muscle in the rat have been described elsewhere (Weddell, Harpman, Lambley and Young, 1940). 


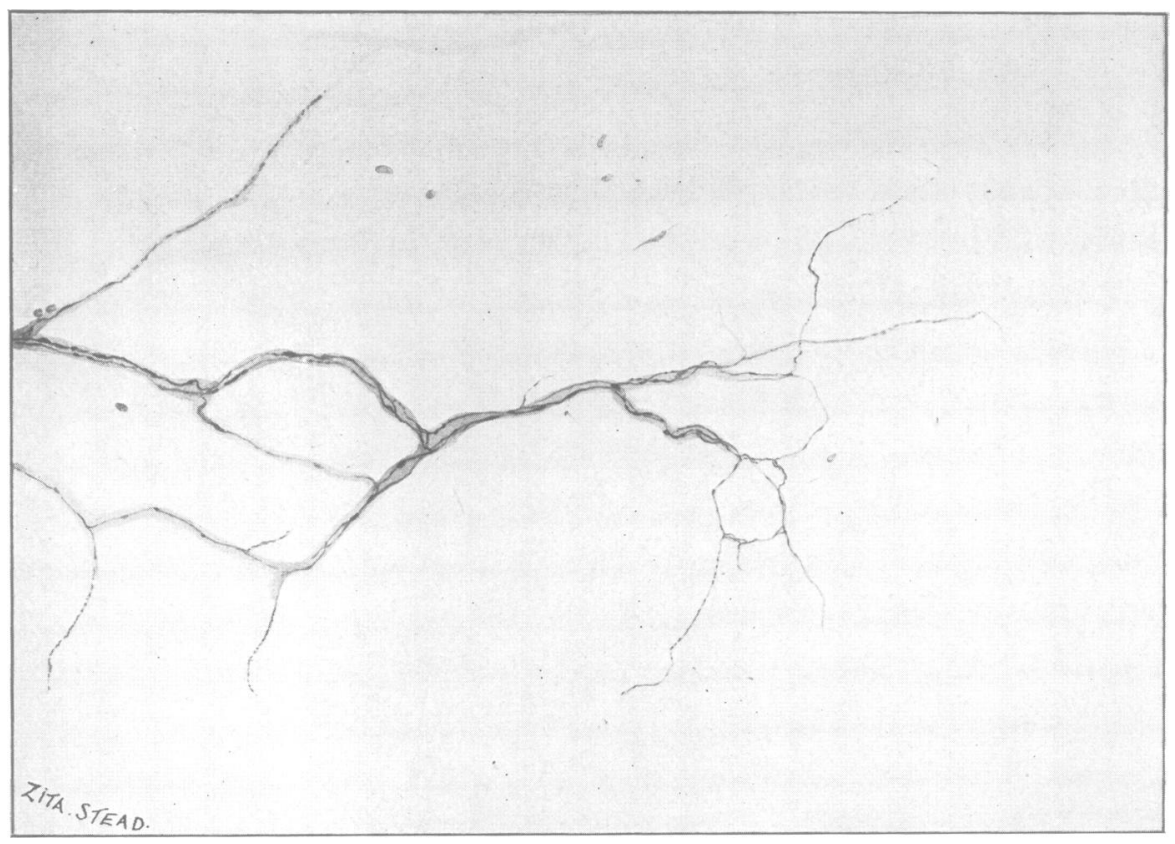

Fig. 8.-Drawing illustrating the plexus of nerve fibres giving rise to free nerve endings in the periosteum of the mandible of the rat. Methylene blue preparation. $\times 700$.

In none of the plexuses mentioned was continuity between nerve fibres observed.

\section{Discussion and Interpretation of Results}

Woollard, Weddell, and Harpman (1940) have established that in human skin pain is subserved by the medullated and non-medullated nerve fibres bearing free nerve endings. Stimulation of morphologically similar fibres and endings in the skin of the ear of the rabbit evokes struggling. Similar somatic fibres and endings occur in teeth (Schafer, 1934; Maximow and Bloom, 1938; Lewinsky and Stewart, 1938a; Tiegs, 1932, 1938; and others), the cornea (Ranvier, 1878; Dogiel, 1890; Attias, 1912; Agababow, 1912; Kadanoff, 1928; Cajal, 1933; present authors; and others), tympanic membrane (Wilson, 1911), mucous membranes (Huber, 1900; Retzius, 1908; Kadanoff, 1927; Cajal, 1933; Lewinsky and Stewart, 1938b, 1939); Stewart and Lewinsky, 1939), serous membranes (Dogiel, 1902; Timofeew, 1902; Michailow, 1908; Boeke, 1932; and others), intermuscular connective tissue (Hinsey, 1927, 1930; Boeke, 1932), surface of tendons (Boeke, 1932), dura mater (Stoehr, 1932), and the adventitia of blood vessels (Woollard, 1926; Hinsey, 1927, 1928, 1930; Woollard et al., 1940), from all of which pain can be aroused (Foerster, 1927; Capps and Coleman, 1932; Waterston, 1933b; Lewis, 1938; Kellgren, 1938; Lewis and Kellgren, 1939; and others). Only free nerve terminals occur in teeth, the central part of the cornea, and the tympanic membrane; from these structures pain only can be provoked (v. Frey, Strughold and Karbe, 1925; 
Clark, 1939). The finding that after cocainization of the cornea conjunctiva a sensation of contact can be evoked from the cornea (Nagel, 1895; Marx, 1921; Pritchard, 1931) is explicable on the grounds of stimulation of extra-corneal sensory nerve endings by deformation, an interpretation suggested by the findings of Carmichael and Woollard (1933). It may be concluded that pain is subserved by free nerve endings. The anatomical work of Ranson (1913, 1914, 1931), the physiological observations of Ranson and Billingsley (1916), the cathode-ray oscilloscope studies of Gasser and Erlanger (1939), Gasser (1935), Heinbecker, Bishop and O'Leary (1934) and Clark, Hughes and Gasser (1935), and the histological and physiological observations of Woollard et al. (1940) concur in showing that pain is transmitted by finer medullated and nonmedullated fibres. The specificity of the nerve fibres and endings subserving pain has been established by the work of Adrian (1926, 1932), Cattell and Hoagland (1931), Heinbecker and Bishop (1935), and Woollard et al. (1940). Woollard et al. (1940) have reviewed the literature in detail, and criticize on grounds of technique an observation by Heinbecker et al. (1934) that throws doubt upon the strict specificity of the fibre group conducting pain impulses.

The physiological and histological observations recorded in the present paper and the facts to which brief reference has been made above lead to the conclusion that in deep fascia, periosteum, peritendinous connective tissue, and tendon substance pain is subserved by free nerve terminals borne by finer medullated and non-medullated nerve fibres. The sensations of pressure aroused in the first and third series of experiments are explained by the occurrence of Vater-Pacini and Golgi-Mazzoni corpuscles in deep fascia; that such a function is subserved by these endings is generally accepted. With regard to tendon substances, the observations here recorded show that in man, subject to the conditions of the experiments performed, pain can only be aroused from tendon substance, as opposed to its immediate coverings, at relatively few points near the musculo-tendinous junction. In the rabbit this is the only region in which nerve fibres and endings can be demonstrated in tendon. The endings are of two types: the first is the neuro-tendinous ending of Golgi, to which is attributed the function of recording tension (Matthews, 1933); the second type is similar to the " accessory" innervation to encapsulated endings subserving touch, cold, and pressure described by Timofeew (1895), Ruffini (1902), Dogiel (1892, 1893, 1904), Sokolow (1899), Sala (1899), Sfameni (1901), Michailow (1908), Ohmori (1923), Jalowy (1935), Woollard (1936, 1937), Woollard et al. (1940) and others. Lavrenko (1938) has shown that this " accessory" innervation is somatic. Woollard (1937) and Woollard et al. (1940) have remarked upon the morphological similarity between "accessory" nerve fibres and endings and the nerve fibres and endings that subserve pain in the human skin; Woollard (1937) has described an " accessory" fibre and ending, derived from the sub-epidermal plexus that subserves pain, to a Krause end bulb. It is presumed that in man pain aroused from tendon is subserved by a terminal nerve apparatus similar to the " accessory " innervation to Golgi tendon endings in the rabbit. Woollard (1936) has suggested that the function of such an " accessory" innervation is to protect the " principal" receptor from damage. 
Goldscheider's (1926) conception that excessive stimulation of nerve-endings recording deformation results in pain may be explained by the above findings.

That the "accessory" fibre to the Golgi tendon ending probably acquires a medullary sheath where it increases in diameter is explicable by Duncan's (1934) theory of progressive myelinization with increasing diameter of nerve fibres. The physiological significance of such changes in diameter is doubtful.

Rosenbach (1884), Gad and Goldscheider (1892, 1898), Thunberg (1902), Alrutz (1909), and Lewis and Pochin (1937), have shown that from human skin two types of pain can be aroused. Woollard et al. (1940) consider that there are all gradations between two main varieties of cutaneous pain, which they describe as follows: " . . . the first being abrupt in onset, hurting little, and lasting for a period corresponding to that during which the stimulus (a fine, sharp needle) is being applied; the second is delayed in onset, rises gradually in intensity, gives the impression of a small stinging area, and disappears slowly." Lewis and Pochin (1937) and Woollard et al. (1940) have recently discussed the various anatomical and physiological explanations which have been advanced to account for this multiplicity of types of cutaneous pain. Woollard et al. (1940) have presented evidence suggesting that the first main type of cutaneous pain is due to stimulation of units of the cutaneous nerve apparatus subserving pain, whilst the second main variety is due to stimulation of bundles of the nerve plexus in question. From the substance of tendon in man pain of only one variety, corresponding to the first type of cutaneous pain, can be aroused. In the substance of tendon in the rabbit only units of the terminal nerve apparatus presumed to subserve pain can be demonstrated. From deep fascia, peritendinous connective tissue, and periosteum pain similar to the first as well as pain resembling the second main variety of cutaneous pain can be aroused, the latter being more often provoked by relatively thick as opposed to fine needles. The second main variety of pain differs from its cutaneous counterpart in that there is no delay in its onset, it is more severe, and described as disagreeable rather than stinging. Histologically, deep fascia and periosteum are supplied by both single nerve fibres and bundles of nerve fibres bearing free nerve endings. The bundles, however, contain relatively fewer fibres than they do in the cutaneous plexuses that subserve pain in human and, by inference, rabbit skin. The present findings thus lend support to the conclusion that the varieties of pain which can be aroused from definitive organs are determined by the morphological disposition of the terminal nerve fibres subserving pain, and not by a multiplicity of afferent dorsal root systems as concluded by Lewis and Pochin $(1937,1938)$; further aspects of the theory propounded by these authors have been discussed elsewhere (Woollard et al., 1940). Heinbecker and Bishop (1935) have recorded observations which they interpret as suggesting that electrical stimulation of pain receptors is essentially nerve fibre stimulation.

Kellgren (1938) states that the introduction of a hypodermic needle through anæsthetized skin into tendon occasionally arouses a "purely local" pain, whilst the injection of 0.05 c.c. of 6 per cent. aqueous sodium chloride solution into the substance of tendon provokes "diffuse" pain felt over a small area 
somewhat distal to the point of injection. The author also states that a sharply localized as well as a diffuse type of pain can be aroused on injection of small quantities of sodium chloride solution into various muscles. Lewis (1938) states that on introduction of a needle through locally anæsthetized skin " each time the needle is jabbed against the tibia a disagreeable diffuse pain is produced, which lasts, at its height, for an appreciable time," and that pain provoked from periosteum is "located with much accuracy." Kellgren (1938) remarks that scratching of the fascial sheath covering the tendon of the tibialis anticus muscle by a needle introduced through locally anæsthetized skin provoked pain " which was always recognized as coming from a point localized regularly about $2 \mathrm{~cm}$. distal to the needle by most subjects and accurately at the needle by a few," In the present experiments pain aroused from tendon, peritendinous connective tissue and periosteum was generally accurately localized. Sometimes, however, pain aroused from periosteum was believed by the subject to be evoked from a point about 1 in. distal to the point of stimulation. The anatomical basis for this fact has not been determined.

\section{Conclusions}

Pain of two main varieties can be aroused from deep fascia, peritendinous connective tissue, and periosteum. The first is similar to the first main type of cutaneous pain described by Woollard et al. (1940); the second main variety corresponds to the second main type of cutaneous pain, but is different in quality and time relation to the stimulus.

From tendon substance pain can only be aroused near musculo-tendinous junctions; it is of only one variety, corresponding to the first main type of cutaneous pain.

The experiments and observations recorded suggest that there is an " accessory" innervation to neuro-tendinous endings of Golgi in man, and that stimulation of the " accessory" fibre or ending gives rise to pain.

There is a similar "accessory" innervation to encapsulated receptors recording touch, pressure, and cold.

The present findings lend support to a previous conclusion that the varieties of pain which can be aroused from definitive organs are determined by the morphological disposition at the periphery of the nerve fibres and endings subserving pain.

\section{REFERENCES}

Adrian, E. D. (1926). J. Physiol., 62, 33.

(1932). The Mechanism of Nervous Action. Philadelphia.

Agababow, G. (1912). Arch. Ophthal., 83, 317.

Alrutz, S. (1909). Skand. Arch. Physiol., 21, 237.

Attias, G. (1912). Arch. Ophthal., 83, 207.

Boeke, J. (1932). Cytology and Cellular Pathology of the Nervous System. Ed. by W. Penfield. New York, 1, 241.

Cajal, S. Ry. (1933). Histology, London.

Capps, J. A., and Coleman, G. H. (1932). An Experimental and Clinical Study of Pain in the Pleura, Pericardium, and Peritoneum. New York.

Carmichael, E. A., and Woollard, H. H. (1933). Brain, 56, 109.

Cattell, McK., and Hoagland, H.(1931). J. Physiol., 72, 392.

Clark, D., Hughes, J., and Gasser, H. S. (1935). Amer. J. Physiol., 114, 69.

Clark, W. E. Le Gros (1939). The Tissues of the Body. Oxford University Press. 
Dogiel, A. S. (1890). Anat. Anz., 5, 483.

(1892). Int. Schr. Anat. Physiol., 9, 76.

(1893). Arch. mikr. Anat., 41, 585.

(1902). Ibid., 59, 1.

(1904). Anat. Anz., 25, 558.

Duncan, D. (1934). J. comp. Neur., 60, 437.

Foerster, O. (1927). Die Leitungsbahnen des Schmerzgefuehls und die chirurgische Behandlung die Schmerzzustande. Berlin and Vienna.

Gad and Goldscheider, A. (1892, 1898). Quoted by T. Lewis and E. E. Pochin (1937). Clin. Sci., 3, 1 .

Gasser, H. S. (1935). Proc. Ass. Res. nerv. ment. Dis., 15, 35.

Gasser, H. S., and Erlanger, J. (1929). Amer. J. Physiol., 88, 581.

Goldscheider, A. (1926). Handb. norm. path. Physiol. Ed. by A. Bethe. Berlin, 11, 131.

Heinbecker, P., and Bishop, G. H. (1935). Proc. Ass. res. nerv. ment. Dis., 15, 226.

Heinbecker, P., Bishop, G. H., and O'Leary, J. (1934). Arch. Neurol. Psychiat., Chicago, 31, 34.

Hinsey, J. C. (1927). J. comp. Neurol., 44, 87.

- (1928). Ibid., 47, 23.

(1930). Proc. Ass. Res. nerv. ment. Dis., 9, 153.

Huber, G. C. (1900). J. comp. Neurol., 10, 135.

Jalowy, B. (1935). Z. Zellforsch., 23, 85.

Kadanoff, D. (1927). Z. Zellforsch., 5, 615. (1928). Ibid., 7, 553.

Kellgren, J. H. (1938). Clin. Sci., 3, 175.

Lavrenko, V. V. (1938). Bull. Biol. et de med. exp., 5,

Lewinsky, W., and Stewart, D. (1938a). Brit. dent. J., 65, 687. (1938b). J. Anat., 72, 531. (1939). Ibid., 74, 53.

Lewis, T. (1938). Brit. med. J., 1, 321.

Lewis, T., and Kellgren, J. H. (1939). Clin. Sci., 4, 47.

Lewis, T., and Pochin, E. E. (1937). Ibid., 3, 67. (1938). Ibid., 3, 141.

Marx, E. (1921). Extrait des annales d'occulistique, 158.

Matthews, B. H. C. (1933). J. Physiol., 78, 1.

Maximow, A. A., and Bloom, W. (1938). Textbook of Histology, 3rd ed., Saunders, Philadelphia and London, 373.

Michailow, S. (1908). Arch. mikr. Anat., 71, 254.

Nagel, W. A. (1895). Pflueger's Arch., 59, 563.

Ohmori, D. (1923). Z. Anat. Entw., 70, 346.

Pritchard, E. A. B. (1931). Brain, 54, 350.

Ranson, S. W. (1913). J. comp. Neurol., 23, 259. (1914). Ibid., 24, 531. (1931). Arch. Neurol. Psychiat., Chicago, 26, 1122.

Ranson, S. W., and Billingsley, P. R. (1916). Amer. J. Physiol., 40, 571.

Ranvier, M. L. (1878). Leçons sur l'histologie du système nerveux., Paris, 2 vols.

Retzius, G. (1908). Proc. roy. Soc., B, 80, 414.

Rosenbach (1884). Quoted by T. Lewis and E. E. Pochin (1937). Clin. Sci., 3, 1.

Ruffini, A. (1902). Bibliogra. anat., 11, 267.

Sala, G. (1899). Anat. Anz., 16, 193.

Schafer, E. A. Sharpey- (1934). Essentials of Histology, 13th ed., 333.

Sfameni, P. (1901). Arch. ital. Biol., 35, 198.

Sokolow, A. (1899). Anat. Anz., 16, 452.

Stoehr, Ph., Jr. (1932). Cytology and Cellular Pathology of the Nervous System. Ed. by W. Penfield. New York, 1, 381.

Stewart, D., and Lewinsky, W. (1939). Proc. roy. Soc. Med., 32, 1054.

Strughold, H., and Karbe, M. (1925). Z. Biol., 83, 189, 201, 207, 297.

Thunberg, T. (1902). Skand. Arch. Physiol., 12, 394.

Tiegs, O. W. (1932). J. Anat., 66, 622.

- (1938). Ibid., 72, 234.

Timofeew, T. (1895). Anat. Anz., 11, 44.

- (1902). Arch. mikr. Anat., 59, 629.

Waterston, D. (1933a). J. Physiol., 77, 251. $(1933 b)$. Lancet, 943.

Weddell, G., Harpman, J. A., Lambley, D. G., and Young, L. (1940). J. Anat., 74, 255.

Wilson, J. G. (1911). Amer. J. Anat., 11, 101.

Woollard, H. H. (1926). Heart, 13, 319.

- (1936). Brit. Med. J., 2, 861 .

- (1937). J. Anat., 71, 480.

Woollard, the late H. H., Weddell, G., and Harpman, J. A. (1940). Ibid., 74, 413. 